\title{
Pathogenesis of Mesial Temporal Sclerosis
}

\author{
C. Elizabeth Pringle, Warren T. Blume, David G. Munoz and L. Stan Leung
}

\begin{abstract}
A relationship between epilepsy and damage to mesial temporal structures has long been recognized. Recent advances have clarified somewhat the issue of whether the pathological changes seen in mesial temporal sclerosis represent the cause or the effect of seizures. This paper reviews mesial temporal sclerosis from an historical perspective and summarizes recent developments in the fields of excitotoxicity, selective vulnerability, and synaptic reorganization as they pertain to the pathogenesis of mesial temporal sclerosis.
\end{abstract}

RÉSUMÉ: Pathogenèse de la sclérose temporale mésiale. La relation qui existe entre l'épilepsie et l'atteinte des structures temporales mésiales est reconnue depuis longtemps. Des progrès récents ont clarifié la question à savoir si les changements anatomopathologiques observés dans la sclérose temporale mésiale est la cause ou l'effet des crises. Dans cet article, nous revoyons la sclérose temporale mésiale du point de vue historique et nous faisons un sommaire des développements récents dans les champs de l'excitotoxicité, la vulnérabilité sélective et la réorganisation synaptique en ce qui a trait à la pathogenèse de la sclérose temporale mésiale.

Can. J. Neurol. Sci. 1993; 20: 184-193

Mesial Temporal Sclerosis (MTS) refers to neuronal loss and gliosis involving the hippocampus and, often, other mesial temporal structures such as the amygdala, uncus and parahippocampal gyrus. It is seen in patients who have had long-standing seizure disorders, status epilepticus, and/or prolonged febrile convulsions. In fact, it is the most common lesion in temporal lobes resected for intractable seizures, found in $50-75 \%$ of such specimens. ${ }^{1-4}$ Synonyms include Ammon's Horn sclerosis and hippocampal sclerosis. However, MTS is the preferred term, as it recognizes the frequent involvement of other mesial temporal structures. All terms imply a specific pattern of nerve cell loss and gliosis in the hippocampus. By tracing the development of current knowledge of the pathogenesis of MTS, one can better understand many recent advances in epilepsy research and even basic concepts of epileptogenesis.

\section{ANATOMY}

The hippocampus is part of the limbic cortex. "Le grand lobe limbique" was the name given by $\mathrm{Broca}^{5}$ for the ring of structures bordering on the neocortical mantle including the hippocampus proper, and the dentate, parahippocampal and cingulate gyri. Papez ${ }^{6}$ described a closed circuit consisting of parts of the hypothalamus, anterior nuclei of thalamus, the cingulate gyrus, and the hippocampal formation which plays a role in emotion. MacLean 7 suggested the term "limbic system" for the circuit described by Papez. Strategically placed between sensory and motor systems subserving somatic function on the one hand and those involved in visceral functions on the other, the limbic system integrates signals from the external and internal worlds. ${ }^{7}$ For further discussion of these concepts see Lopes da Silva et al. ${ }^{8}$

The limbic cortex may be divided into central components consisting of archicortex and peripheral components of periarchicortex. ${ }^{8}$ The hippocampal formation is the only central component in the temporal lobe. Temporal lobe peripheral components include the presubiculum (area 27), parasubiculum (area 49), postsubiculum (area 48) and the entorhinal cortex (area 28).

The hippocampal formation consists of two C-shaped interlocking gyri: the area dentata and the hippocampus proper (= Ammon's Horn) as well as the subiculum (Figure 1). The pyramidal cell layer is the most prominent structure of the hippocampus proper. The apical dendrites of the pyramidal neurons extend through the stratum radiatum, branch repeatedly and spread out in the innermost layer, the stratum lacunosum-moleculare. Pyramidal cell basal dendrites extend toward the alvear surface in the stratum oriens.

The pyramidal cells, which are divided into regions or sectors according to connections, have been labelled in different ways. The most widely used system (and the one employed in this paper) is the "CA" (for cornu Ammonis or Ammon's Horn) system introduced by Lorente de Nó and based on axonal and dendritic connections as determined by Golgi techniques. ${ }^{9}$ This system divides the pyramidal cells of the hippocampus into sectors $\mathrm{CA}_{1}$ to $\mathrm{CA}_{3}$. $\mathrm{CA}_{1}$ region consists of tightly packed, small pyramidal cells. $\mathrm{CA}_{2}$ and $\mathrm{CA}_{3}$ cells are large pyramidal neurons.

From the Department of Clinical Neurological Sciences (C.E.P., W.T.B.); Department of Pathology (Neuropathology) (D.G.M.); Department of Physiology (L.S.L.), University of Western Ontario, London

Received October 27, 1992. Accepted in final form March 1, 1993

Reprint requests to: Dr. W.T. Blume, University Hospital, 339 Windermere, London, Ontario, Canada N6A 5A5 


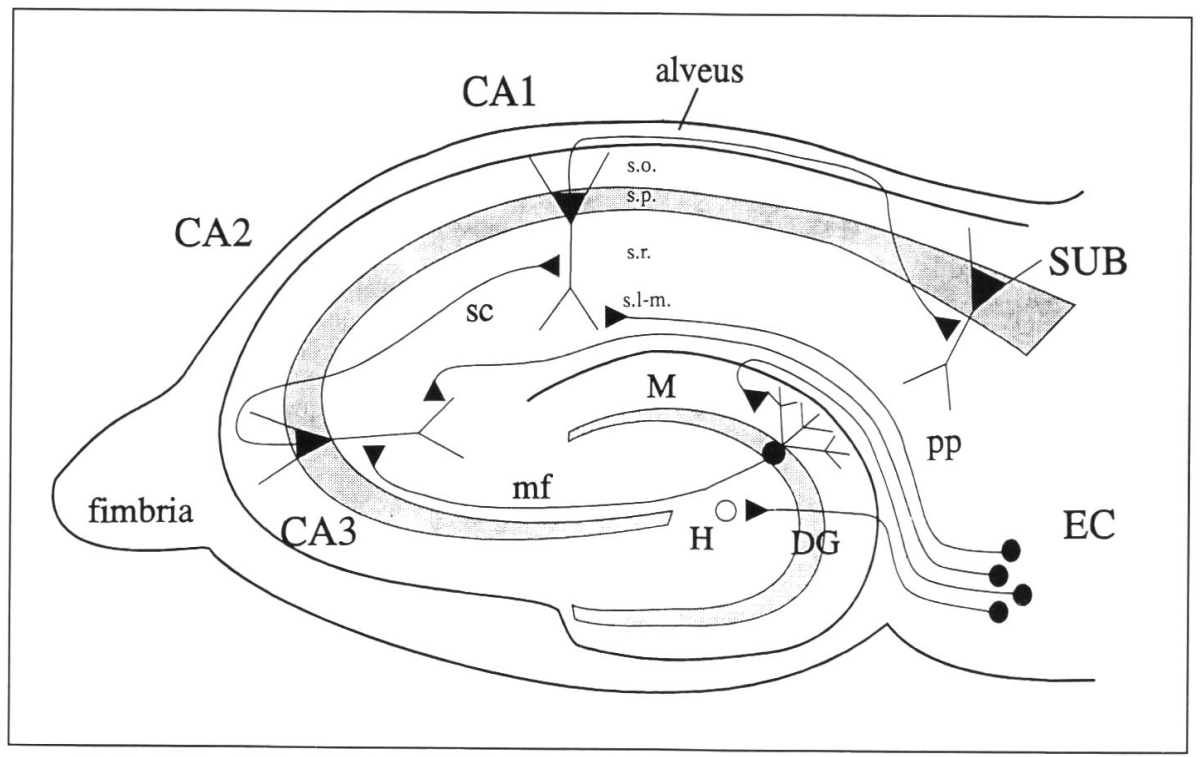

Figure I - The hippocampal formation consists of two C-shaped interlocking gyri (the hippocam. pus proper and the area dentata) and the subiculum. The "hippocampus proper" (= Ammon's Horn) includes the pyramidal cell layer (S.P.), stratum oriens (S.O.), stratum radiatum (S.R.) stratum lacunosum-moleculare (S.L.-M), and the alveus. The area dentata (= dentate gyrus) includes the molecular layer $(M)$, granule cell layer $(D G)$ and the hilus $(H)$. The subiculum (sub) (not shown) continues from $C A$, toward the entorhinal cortex (EC). Perforant path fibres directly excite granule cells, hilar neurons, and $C A_{3}$. $C A$, pyramidal neurons. Mossy fibres $(m f)$ of DG cells project to $C A_{3}$ neurons. Schaffer collaterals (sc) of $C A_{3}$ neurons project to $C A_{1}$ neurons. Inhibitory connections not shown (see text).

$\mathrm{CA}_{3}$ ends at the hilus, the area between the two blades of the dentate granule cells. The hilus, termed $\mathrm{CA}_{4}$ by Lorente de Nó, ${ }^{9}$ consists not of pyramidal cells, but of several types of non-granule cells such as mossy cells and basket cells. ${ }^{10}$ It is also termed the polymorph layer.

A second system of nomenclature, based on cytoarchitectonic criteria, divides the hippocampal formation into 5 sectors, $\mathrm{H}_{1}$ $\mathrm{H}_{5}$, in which $\mathrm{H}_{1}$ is roughly equivalent to $\mathrm{CA}_{1}, \mathrm{H}_{2}$ is roughly equivalent to $\mathrm{CA}_{2}, \mathrm{H}_{3}$ and $\mathrm{H}_{4}$ are equivalent to $\mathrm{CA}_{3}$, and $\mathrm{H}_{5}$ is equivalent to the hilus."

Basket cells in the stratum oriens and stratum pyramidale give off axons which ramify between the pyramidal cells. Oriens-alveus and lacunosum-moleculare interneurons are named for their areas of residence. ${ }^{12}$

The area dentata consists of 3 layers, from outward-inward: molecular, granular and polymorph (= hilus). The supragranular layer forms part of the inner molecular layer. The granular layer consists of tightly packed dentate granule (DG) cells whose dendrites extend into the overlying molecular layer. Non-granule cells of the area dentata can be divided into two general groups: 1) those that exhibit glutamic acid decarboxylase (GAD)- or GABA-like immunoreactivity, and 2) those that do not. ${ }^{13}$ The former group includes: a) basket cells that form an axo-somatic plexus around dentate granule cells, b) axo-axonic cells of granular and molecular layers that innervate the granule cell initial segment, and c) hilar interneurons whose axons form a plexus in the outer molecular layer. The second group is comprised of dentate hilar mossy cells (as distinct from mossy fibres (below)) which form a glutamate-immunoreactive (excitatory) terminal plexus in the inner molecular layer ipsilaterally and contralaterally. ${ }^{13-17}$
The main excitatory afferent to the hippocampus is via the perforant path (PP) that originates in the entorhinal cortex and projects to the area dentata, synapsing onto DG cells, their associated GABAergic interneurons (basket cells) in the molecular and granular cell layers and in the hilus, and on hilar mossy cells. ${ }^{18,19}$ The splay of the perforant path is such that small areas of entorhinal cortex project to extensive lengths of the hippocampus. ${ }^{19}$ Some of this entorhinal input terminates onto the distal two-thirds of the DG cell dendrites in the outer two-thirds of the molecular layer. Other perforant path fibres go to distal apical dendrites of $\mathrm{CA}_{3}$ and $\mathrm{CA}_{1}$ neurons and to the subiculum. ${ }^{9.20}$ Inputs from cortical association areas, subcortical structures, brainstem and other parts of the limbic system (including the amygdala) all converge onto the entorhinal cortex, and funnel to the hippocampus via the perforant path.

In addition to the perforant path, afferent supply to $\mathrm{CA}_{3}, \mathrm{CA}_{1}$ and the area dentata also includes commissural fibres and input from septal and brain stem nuclei. ${ }^{8.21}$ Commissural projections, interconnecting the two hippocampi, have two major components of commissural projections: one from $\mathrm{CA}_{3}$ pyramidal neurons and the other from the area dentata. $\mathrm{CA}_{3}$ projects to contralateral $\mathrm{CA}_{3}$ and $\mathrm{CA}_{1}$; dentate projections arise in the hilus and terminate in the inner one-third of the contralateral stratum moleculare. In addition to the entorhinal cortex, the hilus receives input from several areas, including: cholinergic input from the septum, noradrenergic fibres from the locus coeruleus, and serotinergic afferents from the raphe. ${ }^{16,22}$ Cholinergic fibres terminate throughout the hippocampus, but most prominently in the dentate gyrus and $\mathrm{CA}_{3}$ area. The axons of the DG cells, which are called mossy fibres (MF), synapse on the proximal 

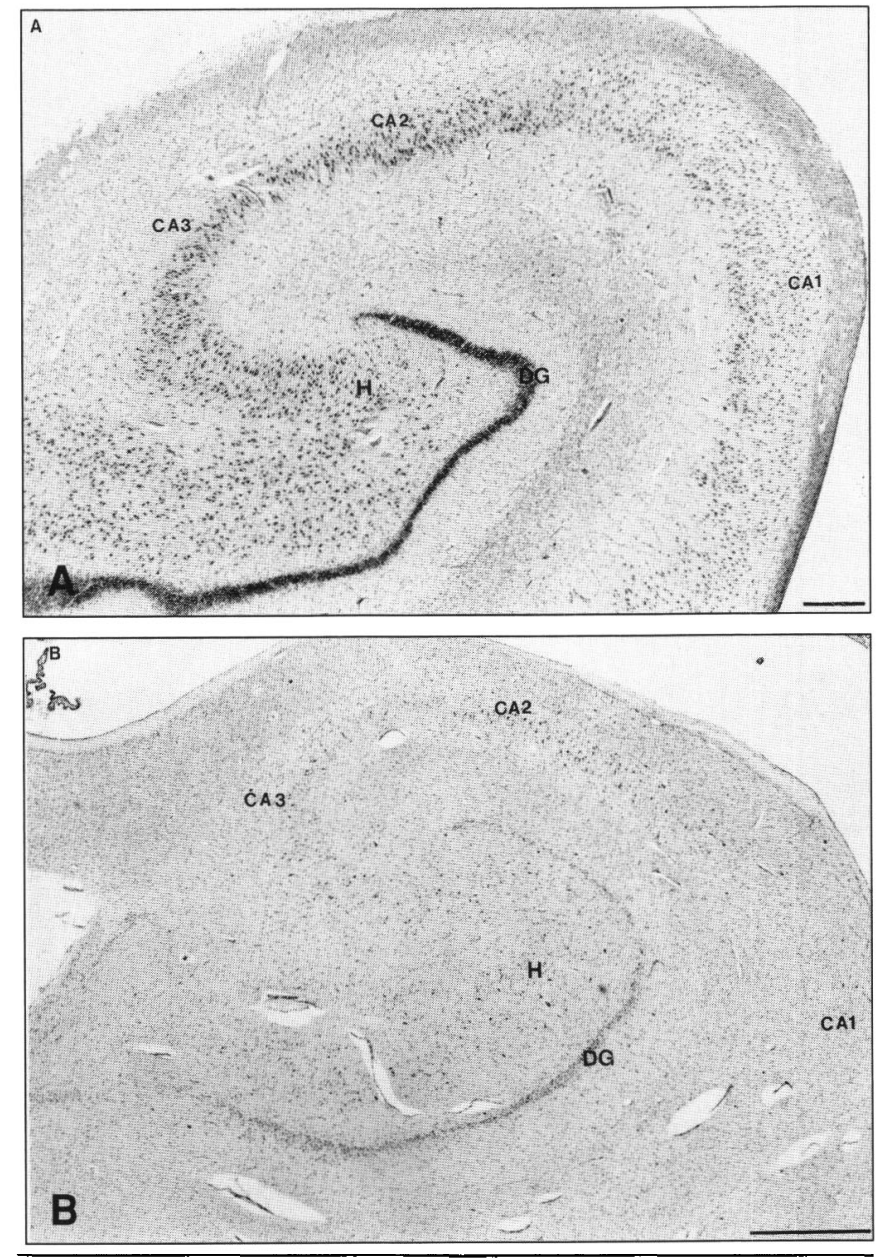

Figure 2 - As compared to the hippocampus of a normal control (Figure 2a), the hippocampus of an epileptic patient with mesial temporal sclerosis (Figure $2 b$ ), shows severe loss of neurons in the $C A_{1}$ and $C A_{3}$ sectors, and hilus with partial preservation of $C A_{2}$ and dentate gyrus. Nissl stain. $H=$ hilus, $D G \doteq$ dentate gyrus. Mesial structures lie to left, lateral to right. Bar $=500 \mu \mathrm{m}$.

apical dendrites of pyramidal cells in $\mathrm{CA}_{3} .{ }^{9} \mathrm{DG}$ cell axon collaterals also reach mossy cells and interneurons of the hilus, and basket cells of the granule cell layer. Hilar interneurons send fibres to DG cell dendrites in the molecular layer, both ipsilaterally and contralaterally. ${ }^{15,16}$ Hilar mossy cells, innervated by the perforant path, send an excitatory axonal plexus to the inner molecular layer. Axons of $\mathrm{CA}_{3}$ cells bifurcate, sending fibres to the fornix for contralateral innervation, and recurrent fibres, called Schaffer collaterals, to apical dendrites of $\mathrm{CA}_{1}$ neurons forming excitatory synapses. ${ }^{10.22}$ Axons from $\mathrm{CA}_{3}$ cells also excite $\mathrm{CA}_{1}$ basket (inhibitory) cells.

Efferents from hippocampal pyramidal cells project mainly, via the subiculum, to the pre, post and parasubiculum, and to the entorhinal cortex, the anterior cingulate cortex, the septum, the amygdala and other regions. ${ }^{8}$

\section{Pathology}

In MTS, there is consistent hippocampal nerve cell loss and gliosis affecting $\mathrm{CA}_{1}, \mathrm{CA}_{3}$ and the hilus, which relatively spares $\mathrm{CA}_{2}$ and the dentate granule (DG) cells (Figure 2). The affected sectors are not cavitated, but rather have a shrunken, dense appearance. There is a fairly sharp margin at the junction of the sclerotic $\mathrm{CA}_{\text {, }}$ and the normal-looking subiculum. Less common is "end folium sclerosis" consisting of hilar and $\mathrm{CA}_{3}$ pyramidal cell loss and survival of most $\mathrm{CA}_{1}$ pyramid cells. ${ }^{2.4}$ Houser et al. ${ }^{23}$ found two patterns of granule cell distribution in human temporal lobectomy specimens: 1) a compact granule cell layer whose border with the molecular layer was sharp as in controls and 2) a wider and less dense granule cell layer with varying extension of the granule cell somata into the molecular layer. This latter was associated with marked neuronal loss in the polymorph region of the hilus. Most patients with such granule cell dispersion had had febrile convulsions or seizures associated with meningoencephalitis.

\section{Clinical Data}

A relationship between epilepsy and damage to these mesial temporal structures has been recognized since 1825 when Bouchet and Cazauvieilh observed abnormalities of Ammon's horn in 9 of 18 brains of epileptics. ${ }^{24}$ In 1868 Meynert examined the brains of 20 patients with epilepsy and temporal lobe atrophy and described 2 types of pathology: the "classical" hippocampal atrophy as described by Bouchet and Cazauvieilh and a more diffuse pattern, affecting widespread areas of the brain. ${ }^{25}$ However, it was not until 1880 that the exact nature of the relationship between seizures and brain damage began to be explored. In that year, Sommer reviewed the literature on the histology of the hippocampus in patients with epilepsy, which at that time amounted to 90 cases, ${ }^{26}$ and described one of his own cases in detail. He documented severe neuron loss in a restricted area of the pyramidal band which became known as "Sommer's sector" (and is now known as $\mathrm{CA}_{1}$ ). Sommer coined the term "Ammon's Horn Sclerosis" and proposed that the lesions were the cause of seizures. In that same year, Pfleger ${ }^{27}$ examined the brains of patients dying shortly after status epilepticus and concluded that the hippocampal lesions were the result of local circulatory and metabolic disturbances related to seizures. In 1927 Spielmeyer found that the brains of patients who had died in status epilepticus had severe neuron loss in $\mathrm{CA}_{1}$ and $\mathrm{CA}_{3}$ as well as the cerebellum. ${ }^{28} \mathrm{He}$ concurred with Pfleger that the changes were secondary to seizures and, based on neurosurgical accounts of pallor of the brain intraictally, hypothesized that vascular spasm at the onset of an epileptic attack led to ischaemia. Scholz, in 1951, also felt that the pathology was the result of seizures; however, he emphasized that it involved not only the hippocampus, but also the cerebellum, thalamus, and scattered areas of the neocortex. ${ }^{29} \mathrm{He}$ suggested that the pattern of damage reflected different degrees of vulnerability to hypoxia and an increased demand for oxygen with seizures, and that the immature nervous system was particularly predisposed to such ictal insult.

Earle, Baldwin and Penfield' in 1953 found mesial temporal damage in 100 of 157 (63\%) surgical resections for intractable seizures. Based on the marked improvement of seizure control after surgery, they felt that the damage was the cause of complex partial seizures. They coined the term "incisural sclerosis" and proposed that the birth process transiently deformed the skull and subsequently herniated the mesial portions of temporal lobes and their nutrient vessels against the stiff edge of the tentorium. This, in turn, would compress the posterior cerebral artery and/or the anterior choroidal artery and result in ischaemia. After several years, such ischaemic regions would "ripen" into an epileptogenic focus. In 1956, Gastaut expanded this concept by suggesting that ischaemia could also be consequent to edema caused by other events such as head injury or stroke. ${ }^{30}$ 
Subsequent data failed to support the concept of incisural sclerosis. Although Meyer, Falconer and Beck ${ }^{31}$ agreed that MTS caused complex partial seizures (again, from the marked improvement after temporal lobectomy in patients with MTS), they could only rarely obtain a history of traumatic birth. However, they did find that all cases with typical MTS had onset of seizures at less than ten years of age. They hypothesized that MTS was the result of some hypoxic-ischaemic insult in early childhood. Norman ${ }^{32}$ and Ounsted et al. ${ }^{33}$ showed that the distribution of neuronal loss and gliosis seen in association with MTS differed from what would be expected from posterior cerebral artery occlusion: the occipital lobes were spared and neocortical regions beyond the posterior cerebral distribution were involved. Veith ${ }^{34}$ added further doubt when he studied stillborn and neonatal deaths and found that temporal lobe herniation was not a significant factor.

Falconer and Taylor ${ }^{3}$ were the first to suggest that MTS might be both the cause and effect of seizures. They felt that the onset of seizures in early childhood, from whatever cause, led to ischaemic damage which would then ripen into an epileptogenic focus. Margerison and Corsellis ${ }^{2}$ felt that the scarring perpetuated the seizure disorder and, by its localization, influenced its clinical manifestations. This was supported by the better post-lobectomy seizure control among patients with MTS than among those with other or no lesions. ${ }^{3}$ The view of Falconer and Taylor was further supported by a recent population-based case-control study by Rocca et al..$^{35}$ which found a significant association between complex partial seizures and neonatal convulsions, febrile seizures (especially atypical febrile seizures) and viral encephalitis. No association was found between complex partial seizures and prematurity, prolonged labour or perinatal asphyxia. Bruton $^{4}$ also found that a high proportion of patients exhibiting MTS in surgically removed hippocampi had experienced febrile seizures or status epilepticus in early life. Most of Bruton's cases were "cryptogenic" epilepsy, but in a small proportion MTS was found in association with a tumour or malformation of the temporal lobe. Interestingly, these cases with a structural abnormality had a low incidence of febrile convulsions in childhood. ${ }^{4}$ It has been suggested that the location of the structural abnormality in the temporal lobes of these cases may stimulate the perforant path. ${ }^{13}$ Sagar and Oxbury ${ }^{36}$ found severe neuron loss in $\mathrm{CA}_{1}$, end folium and dentate gyrus to be associated with prolonged and/or lateralized childhood convulsions. Only a few patients with milder $\mathrm{CA}_{1}$ and end folium neuronal loss with dentate granule cell preservation had had childhood convulsions.

Unfortunately, quantitative neuroanatomic methods have not consistently supported the role of seizures in creating MTS. While Mouritzen-Dam ${ }^{37}$ was able to correlate frequency of grand mal seizures and hippocampal neuronal loss, Babb et al..$^{38,39}$ found no clear relationship.

\section{EXPERIMENTAL DATa}

Regardless of whether they felt that MTS was the cause or effect of seizures, all authors until approximately 1970 felt that the ultimate mechanism of production of MTS involved ischaemia. However, a series of studies on experimentallyinduced seizures, beginning with those of Meldrum and colleagues, ${ }^{40-46}$ disproved this hypothesis. Using bicuculline and allylglycine, Meldrum, Brierley and colleagues induced seizures in ventilated, anaesthetized baboons and controlled the animals' $\mathrm{P}_{\mathrm{a}} \mathrm{O}_{2}, \mathrm{pH}, \mathrm{P}_{\mathrm{a}} \mathrm{CO}_{2}$, blood pressure and temperature. Motor convulsions were eliminated by the use of pharmacologic paralysis. In spite of control of these metabolic and circulatory factors, brain damage appeared in a distribution similar to that seen in humans with MTS. They concluded that the damage was related to the electrical activity per se and not to an hypoxic-ischaemic mechanism. This conclusion is supported by the fact that the histopathological changes seen in MTS differ from the necrosis of hippocampus and subiculum seen in hypoxia. ${ }^{47}$ Furthemore, although the damage of MTS and ischaemia have a similar hippocampal distribution, there are ultrastructural differences between the 2 lesions. ${ }^{48}$ As well, the temporal course is different: neuronal death occurs over minutes to hours in epilepsy but evolves over hours to days in ischaemia. ${ }^{49}$ However, no major distinction between epileptic and ischaemic damage to the hippocampus exists except for a possibly greater involvement of the subiculum by ischaemia ( $R$. Auer, personal communication and ${ }^{49}$ ).

Subsequent studies have shown that in such experimental models, neurons are neither hypoxic nor ischaemic: cerebral blood flow actually increases, ${ }^{41,44}$ as do sagittal sinus $\mathrm{PO}_{2}{ }^{50}$ and brain tissue oxygen tension, ${ }^{50}$ suggesting that the increase in blood flow exceeds the requirements of the metabolizing tissue. Furthermore, although histopathologic changes are seen after 1 hour of seizure activity, ${ }^{48}$ the phosphorylation state of the adenine nucleotide pool remains close to normal over a two hour seizure period, 51.52 indicating that the energy charge of the cells of the hippocampus remains virtually unperturbed.

How then is the damage produced? The probable answer lies in Olney's excitotoxic hypothesis: that neurons can be "excited to death".53-55 Presentation of this hypothesis will be introduced by an overview of excitatory and inhibitory pathways of the hippocampus, excitatory neurotransmission within the hippocampus, and studies of hippocampal excitation and their significance for mesial temporal sclerosis (MTS).

\section{Relevant Physiology}

Input to the hippocampus ignites both excitatory and inhibitory systems within this structure. Thus perforant path stimulation innervates the following excitatory chains: 1) DG cells - (mossy fibres) $\rightarrow \mathrm{CA}_{3}$ neurons - (Schaffer collaterals) $\rightarrow \mathrm{CA}_{1}$, 2) $\mathrm{PP} \rightarrow \mathrm{CA}_{1}$, 3) $\mathrm{PP} \rightarrow \mathrm{CA}_{3}$ (Figure 1).

Several inhibitory interneurons may modulate these excitatory sequences. Of these, the functions of basket cells and oriensalveus $(O A)$ interneurons in the $C A$, region have been clarified. Basket cells receive excitatory synapses from hippocampal afferent fibres in the stratum radiatum and stratum oriens and also from collaterals from pyramidal cell axons. OA interneurons receive excitatory afferents in stratum radiatum and the alveus and also from pyramidal cell axon collaterals. ${ }^{12}$ These cells form inhibitory synapses on pyramidal cell somata and initial parts of apical dendrites. Significantly, afferent fibres may excite these inhibitory interneurons before exciting afferent synapses, creating feed-forward inhibition. Lacunosum-moleculare interneurons may also mediate feed-forward inhibition from major hippocampal afferents. ${ }^{12}$ In addition, as suggested above, excitation of pyramidal cells in CA fields or granule cells may lead to recurrent inhibition through basket or OA interneurons.

The following briefly outlines some experimental results illustrating inhibition in the hippocampus. Perforant path (PP) 
stimulation can elicit population spikes in DG cells and sequential discharges there. ${ }^{15}$ A population spike, extracellularly recorded, represents simultaneously-occurring action potentials from a large number of neurons - DG cells in this instance. However, some dentate non-granule cells (mossy and basket) may discharge more readily upon PP stimuli than do DG cells. ${ }^{13.17}$ Hilar mossy cells via their connections may effect and amplify both feed-forward and feedback inhibition. Such inhibition is manifested by a lower response to the second of a stimulus pair, a phenomenon known as paired pulse inhibition. ${ }^{17,56.57}$ These inhibitions might combine to produce the hyperpolarization that occurs in some DG cells on PP stimulation. ${ }^{17}$ In vivo, $\mathrm{CA}_{3}$ action potential bursts may hyperpolarize $\mathrm{CA}_{1}$ somata, presumably via basket cell innervation. ${ }^{58}$

In summary, inhibitory mechanisms are also brought into play by afferent stimuli. Feed-forward inhibition is effected by the following postulated sequences: ${ }^{12,56}$ 1) PP (excitatory) $\rightarrow$ mossy cells (excitatory) $\rightarrow$ basket cells (inhibitory) $\rightarrow$ DG cells, 2) PP $\longrightarrow$ basket cells (inhibitory) $\rightarrow$ DG cells, 3) $\mathrm{CA}_{3}$ $\rightarrow$ basket, OA, or L-M (inhibitory) $\rightarrow \mathrm{CA}_{1}$. Feedback inhibition occurs as follows: 1) PP $\rightarrow$ DG cells (excitatory) $\rightarrow$ mossy cells $\rightarrow$ basket cells $\rightarrow$ DG cells, or 2 ) PP $\rightarrow$ DG cells $\longrightarrow$ basket cells $\longrightarrow$ DG cells. Axons of dentate hilar mossy cells also reach contralateral dentate basket cells, thereby inhibiting contralateral DG cells.

\section{Excitatory Amino Acids and Their Receptors}

The major excitatory neurotransmitters of the CNS are the excitatory amino acids (EAAs), particularly glutamate and aspartate. ${ }^{59}$ These amino acids are excitatory as they depolarize membranes. There are three major types of glutamate receptors: kainate/ $\alpha$-amino-3-hydroxy- 5 methyl-4-isoxazole proprionic acid (kainate/AMPA) receptors, N-methyl-D-aspartate (NMDA) receptors, and metabotropic (Qp) receptors. ${ }^{60}$ Kainate/AMPA receptors activate an ion channel permeable to $\mathrm{Na}^{+}$and $\mathrm{K}^{+}$ions and likely mediate fast excitatory transmission at glutaminergic synapses. About $25 \%$ of hippocampal kainate receptors are also linked to calcium channels. ${ }^{61}$ NMDA receptors are about 10 times more permeable to $\mathrm{Ca}^{++}$than to $\mathrm{Na}$; their activation can cause a massive $\mathrm{Ca}^{++}$influx into neurons. The metabotropic receptor, linked to a $\mathrm{G}$ protein, activates phospholipase $\mathrm{C}$ and generates inositol 1, 4, 5 trisphosphate which mobilises calcium from intracellular stores. Of these, NMDA receptors are the best known, possibly because they allow glutamate to regulate $\mathrm{Ca}^{++}$ influx into neurons and play major roles in longterm potentiation (LTP) and excitotoxicity.

The receptor types differ not only in their physiological functions and pharmacological profiles, but also in their anatomical distribution. The $\mathrm{CA}_{\text {, }}$ section of the human hippocampus, where the Schaffer collaterals terminate, contains the highest density of NMDA receptors in the CNS, whereas the mossy fibre termination zone of $\mathrm{CA}_{3}$ is high in kainate/AMPA receptors. ${ }^{59}$

Glutamate and aspartate act as transmitters in synapses of the perforant path, axons of CA neurons, and mossy fibres. ${ }^{8.62-64}$ Glutamate is the most likely perforant path transmitter whereas aspartate may predominate in commissural projections.

Acetylcholine $(\mathrm{ACh})$, found mainly in afferent terminals of extrinsic origin, acts chiefly to depolarize membranes by abolishing two hyperpolarizing $\mathrm{K}^{+}$currents: a voltage-dependent one and a low threshold $\mathrm{Ca}^{++}$-activated one. ${ }^{65}$ Thus, acetylcholine may prolong action potential discharges. ${ }^{8}$ Moreover, ACh may depress GABAergic interneurons and thus disinhibit hippocampal pyramidal cells. ${ }^{66.67}$

GABA is the main transmitter of inhibitory connections, arising from local interneurons such as basket cells and $O A$ interneurons. Hilar cells of the contralateral area dentata and fibres from the medial septal area also have GABA terminals. ${ }^{68}$ The physiological effect of GABA is hyperpolarization either because of an increase in $\mathrm{Cl}^{*}$ conductance $\left(\mathrm{GABA}_{\mathrm{A}^{-}}\right.$type receptor) or increased $\mathrm{K}^{+}$conductance $\left(\mathrm{GABA}_{\mathrm{B}}\right){ }^{8}$ Although GABA hyperpolarizes the soma and initial segment, it depolarizes apical dendrites of $\mathrm{CA}_{3}$ and $\mathrm{CA}_{1}$ cells ${ }^{69}$ and somata of $\mathrm{DG}$ cells. $^{70}$ The depolarizing response of GABA is facilitated by an increase in extracellular $\mathrm{K}^{+}$concentration as occurs after tetanic stimulation. ${ }^{71}$ Finally, GABA receptors mediating the hyperpolarizing response may fatigue with use. ${ }^{72}$

Effects of catecholamines and neuropeptides are modulatory and will not be discussed here.

\section{Experimental Data Supporting Excitotoxicity as Mechanism of Damage}

Two principal experimental models have been employed to study physiological and pathological effects of excess excitation in the hippocampus: sustained electrical stimulation and kainic acid administration.

Low frequency PP stimulation, presumably representative of normal afferent input from the entorhinal cortex to the hippocampus, exhibited DG cell "paired pulse inhibition" (a reduction in amplitude of the population spike response to the second stimulus of a pair) with interstimulus intervals of 5-25 msec. ${ }^{8}$ Sustained PP stimulation for 1-5 minutes temporarily reduced paired pulse inhibition. ${ }^{8}$ Longer (25-90 minutes) stimulation irrevocably abolished paired pulse inhibition and the number and amplitude of DG cell population spikes increased. ${ }^{8}$ Significantly, dentate hilar cells physiologically deteriorated prior to loss of DG cell paired-pulse inhibition. ${ }^{17}$

Sustained $\mathrm{CA}_{3}$ or PP stimulation produces the same effect in $\mathrm{CA}_{1}$ cells: repetitive discharges and a loss of recurrent inhibition. ${ }^{13}$ Therefore, sustained electrical stimulation of hippocampal afferents decrease or abolish inhibitory mechanisms within the hippocampus. Is there a pathological correlate?

Sloviter, ${ }^{15}$ electrically stimulated the perforant path of normal rats once per minute for 24 hours and produced a pattern of pathological damage which resembled that of human hippocampal sclerosis, and particularly that of "end folium sclerosis". Hilar mossy cells and $\mathrm{CA}_{3}$ pyramidal cells were destroyed while dentate granule cells, $\mathrm{CA}_{2}$ pyramidal cells and basket cells were relatively spared. $\mathrm{CA}_{3}$ damage only occurred if $\mathrm{DG}$ cell discharges were evoked; if the stimulus was subthreshold to action potential occurrence, no damage occurred. These findings suggest that damage to the pyramidal cells was due to excessive stimulation by DG cells via mossy fibres. As mentioned, a transmitter of the mossy fibre pathway is glutamate. ${ }^{73.74}$ Hippocampal neuronal loss from perforant path stimulation can be prevented by glutamate receptor antagonists. ${ }^{75}$ Sloviter and Dempster have also shown that the "epileptic pattern" of damage can be replicated by intraventricular administration of glutamate or aspartate. ${ }^{76}$ Furthermore, Monaghan et al. ${ }^{77}$ have found a high density of glutamate receptors in the exact area innervated by the mossy fibres and damaged by perforant pathway stimulation. 
The main difference between these entities was in $\mathrm{CA}_{1}$ pyramidal cells which are often lost in hippocampal sclerosis but were mostly preserved with PP stimulation in anaesthetized animals. However, sustained $\mathrm{CA}_{3}$ stimulation can destroy $\mathrm{CA}_{1}$ cells. ${ }^{13}$ More importantly, perforant path stimulation in unanaesthetized rats leads to extensive $\mathrm{CA}_{1}$ damage. ${ }^{78}$ Neuronal losses from PP stimulation were associated with the above-described decrease in both feed-forward and recurrent inhibition of granule cells and a decrease of recurrent inhibition of $\mathrm{CA}_{1}$ pyramidal cells. Permanent hyperexcitability in dentate granule and $\mathrm{CA}_{1}$ pyramidal cell populations developed.

Damage from PP stimulation occurred primarily in areas innervated directly by the PP or by DG cells. Thus dendritic swellings appeared on the distal two-thirds of DG cell dendrites and distal portions of $\mathrm{CA}_{3}$ and $\mathrm{CA}_{1}$ apical dendrites as well as $C A_{1}$ basal dendrites. ${ }^{15}$ All receive direct $P P$ innervation. Indirect innervation of basal and apical dendrites of $\mathrm{CA}_{1}$ from $\mathrm{CA}_{3}$ may also have contributed to this. ${ }^{13} \mathrm{CA}_{3}$ proximal apical dendrites, direct recipients of DG axons as mossy fibre terminals, and hilar mossy cells, also exhibited dendritic swellings. ${ }^{15}$ Such dendritic swellings resembled those found by Scheibel et al. ${ }^{79}$ in humans with temporal lobe epilepsy.

Pathological changes produced by sustained $\mathrm{PP}$ and $\mathrm{CA}_{3}$ stimulation may explain the alteration in DG cell and $\mathrm{CA}_{1}$ responses. Despite loss of inhibition with perforant path stimulation, GABA-immunoreactive cells survived in all hippocampal regions. ${ }^{13}$ Moreover, the aforementioned loss of inhibition in $\mathrm{CA}_{1}$ cells ipsilateral to perforant path stimulation was immediately reversed by contralateral perforant path stimulation. These data lead Sloviter" to the "dormant basket cell" hypothesis of hippocampal sclerosis: i.e., inhibitory neurons survive in these situations but are rendered hypofunctional by a loss of excitatory systems that normally evoke inhibition. Thus, undamaged dentate inhibitory cells become "dormant" because destruction of excitatory hilar neurons, possibly mossy cells, removes the tonic excitatory input to such inhibitory cells. Destruction of $\mathrm{CA}_{3}$ cells would decrease input to surviving basket cells which normally inhibit $\mathrm{CA}_{1}$ in a feed-forward manner.

Kainate (or kainic acid, KA) is a glutamate analogue which has been used as an experimental epileptogenic agent. As with PP stimulation, KA reduced paired pulse inhibition and lead to multiple DG discharges upon PP stimulation. ${ }^{14}$ Systemically administered KA will induce seizure-related hippocampal damage similar to MTS and to that resulting from PP electrical stimulation (i.e., affecting $\mathrm{CA}_{1}, \mathrm{CA}_{3}$ and hilar polymorph neurons but sparing $\mathrm{CA}_{2}$ and $\mathrm{DG}$ cells). ${ }^{80-82} \mathrm{CA}_{3}$ pathology occurred at the site of mossy fibre synapses suggesting that DG discharges were responsible. ${ }^{82}$ This damage is independent of motor convulsions. ${ }^{83}$ However, it is dependent on the presence of excitatory afferents to the hippocampus. Thus, transection of the perforant path decreased kainic acid-induced pyramidal cell damage ${ }^{84}$ and severing the mossy fibres decreased $\mathrm{CA}_{3}$ pyramidal neuron loss. ${ }^{85}$ Blocking epileptic activity with diazepam also protected the hippocampus from KA-induced pathology. ${ }^{84}$

In addition to perforant path stimulation and kainic acid administration, a third animal model of temporal lobe epilepsy, kindling, can produce progressive neuronal loss in the hilus in association with repeated seizures. ${ }^{86.87}$

Further evidence that hippocampal neuronal loss can occur in a variety of models comes from pilocarpine induced limbic seizures in rats: dentate hilar and $\mathrm{CA}_{3}$ damage occurred. ${ }^{88}$ Pretreatment with several types of antiepileptic drugs prevented the neuropathological changes. ${ }^{88.89}$

\section{Synaptic Reorganization}

An exciting development in research on MTS has been the demonstration of synaptic reorganization in the hippocampi in both experimental epilepsy models ${ }^{90.91}$ and in humans with temporal lobe epilepsy. ${ }^{23.92-94}$ Intraventricular administration of kainic acid (KA) in rats preferentially destroys $\mathrm{CA}_{3}$ and hilar neurons and thus is a good model for MTS as indicated earlier. ${ }^{81,95}$ After an interval during which this procedure was associated with a decrease in synaptic density in $\mathrm{CA}_{1}$ stratum radiatum (from $\mathrm{CA}_{3}$ loss) and inner dentate molecular layer (from dentate hilar loss), new synapses reformed in these regions within 6-8 weeks. ${ }^{95}$ Destruction of $\mathrm{CA}_{3}$ and the dentate hilus by this model was also associated with mossy fibre sprouting. As outlined in a previous section, hippocampal mossy fibres originate from dentate granule (DG) cells and project upon $\mathrm{CA}_{3}$ pyramidal neurons. Mossy fibre terminals can be quantified by autoradiographic visualization of KA (agonist for kainate/AMPA glutamate receptor) and by the Timm method. The latter stains mossy fibre terminals because of their high zinc content. Represa et al..$^{96}$ found a dark Timm positive band and an increase in KA binding sites in the supragranular layer reflecting mossy fibre sprouting in an area where they are not normally present. Mossy fibres sprouted into the dentate supragranular layer also upon PP kindling in the rat. Low frequency stimulation provoking only focal seizures also produced mossy fibre sprouting, but to a lesser extent. ${ }^{97}$ Mossy fibre sprouting resulting from removal of perforant path and commissural afferents to the area dentata of the rat were shown by Golgi-EM technique to innervate dendrites of the DG cells, their cells of origin. ${ }^{91}$ Using antidromic stimulation, Tauck and Nadler ${ }^{98}$ demonstrated increased excitation of such abnormally sprouting mossy fibres.

In an autoradiographic post mortem study of epileptic children, Represa et al. ${ }^{92}$ found increased mossy fibres in $\mathrm{CA}_{3}$ and area dentata as reflected in increased kainate binding density. Further evidence of mossy fibre sprouting in human temporal lobe epilepsy comes from dynorphin immunoreactivity (IR) studies. Dynorphin, an opioid peptide in mossy fibres, is found in the hilar (polymorph) region of the dentate gyrus in normals. In temporal lobe epilepsy, dynorphin IR is also found in the molecular and DG cell layers the extent of which correlates with neuronal loss in dentate hilar and $\mathrm{CA}_{3}$ fields and with granule cell dispersion. ${ }^{23.94}$ Finally, Sutula et al. ${ }^{93}$ found intense Timm staining and abundant mossy fibre synaptic terminals in the dentate inner molecular and supragranular layers of temporal lobes resected for refractory complex partial seizures. Eight of their 10 patients had MTS. Ultrastructural study confirmed that Timm granules seen with light microscopy corresponded to mossy fibre synaptic terminals. These findings provide morphological evidence of mossy fibre sprouting and synaptic reorganization in humans with temporal lobe epilepsy as well as experimental epilepsy. Combined with the physiological data, they suggest increased DG excitation in this situation. ${ }^{98}$ These data suggest that reorganization of the mossy fibre pathway contributes to the epileptogenicity of the hippocampus in mesial temporal sclerosis. However, such reorganization may appear in some epileptogenic clinical and experimental situations, such as kindling or 
certain cases of temporal lobe epilepsy, without measurable neuronal loss. ${ }^{93,97}$

A correlation also exists between improvement in seizure frequency following temporal lobectomy and presence of mossy fibre sprouting in resected temporal lobes. ${ }^{94}$ Thus, it appears that recurrent excitation of DG cells from aberrant synapses lowers the seizure threshold.

Mechanisms of this synaptic reorganization may involve partial deafferentation of DG cells when dentate hilar cells, which give rise to association and commissural pathways terminating on DG cells, are damaged along with $\mathrm{CA}_{3}$ and $\mathrm{CA}_{1}$ cells by mechanisms already discussed. Such partial denervation may promote mossy fibre sprouting. ${ }^{85}$ The loss of polymorph neurons may also account for mossy fibre sprouting in the kindled rat. ${ }^{87}$ However, Sutula et al. have shown that mossy fibre sprouting occurs with seizures induced by perforant path stimulation, even in the absence of overt hilar damage. ${ }^{97}$

More recently, it has been demonstrated that nerve growth factor (NGF) messenger RNA (mRNA) was dramatically increased in the DG cells within one hour of limbic seizures in experimental rats. ${ }^{99}$ Intra-hippocampal injections of antibodies to NGF inhibit mossy fibre sprouting. ${ }^{100}$ These data suggest that DG cell seizure activity may directly cause mossy fibre sprouting via release of NGF, a substance known to increase neurite extension. ${ }^{101.102}$ This, then, may provide the morphologic substrate of kindling, the production of a permanent epileptic state by the repeated activation of neural pathways. ${ }^{103}$ Brain-derived neurotrophic factor (BDNF) mRNA increased in the hippocampus, amygdala and pyriform cortex whereas NGF mRNA increased in DG cells and pyriform cortex after hippocampal kindling. ${ }^{104}$

Other genes, including c-fos, neuropeptide-Y gene, and the pro-enkephalin gene, are also activated by seizures. ${ }^{105-107}$ This has led some to question the specificity of gene activation in epilepsy models. However, it is notable that some mRNAs within DG cells are unaffected or even decreased (e.g., pre-prodynorphin) by seizures, ${ }^{107}$ suggesting at least some degree of specificity of gene activation.

\section{Ultrastructural Changes}

Ultrastructural changes in seizure-induced hippocampal lesions give further insights into possible mechanisms of their causation. It has been shown that experimentally-induced seizures produce distended dendrites with swollen mitochondria in $\mathrm{CA}_{1}$ and $\mathrm{CA}_{3} \cdot{ }^{108}$ These areas of swelling are densely loaded with intramitochondrial calcium. ${ }^{109}$ There are a number of proposed mechanisms for how the damage is caused. Glutamate and aspartate increase post-synaptic membrane permeability to $\mathrm{Na}^{+}$via both NMDA and non-NMDA receptor gated ion channels, with a subsequent increase in $\mathrm{Na}^{+}$uptake. ${ }^{10}$ Water follows $\mathrm{Na}^{+}$osmotically, causing cell swelling which may be a marker of excitotoxin release. ${ }^{11}$ An additional mechanism involves the opening of calcium channels: both receptor-gated channels stimulated directly by EAAs and voltage-dependent channels opened as a result of $\mathrm{Na}^{+}$-induced depolarization allow calcium influx. Such influx produces mitochondrial dysfunction, protease and lipase activation, and free radical activation. Each factor could be lethal for cells without protective mechanisms. ${ }^{112-114}$ Both the $\mathrm{Na}^{+}$and the $\mathrm{Ca}^{++}$influx are probably involved in EAA-induced damage. ${ }^{113}$

\section{Selective Vulnerability}

The question of why neurons of $\mathrm{CA}_{1}, \mathrm{CA}_{3}$ and $\mathrm{CA}_{4}$ are damaged while $\mathrm{CA}_{2}$ and $\mathrm{DG}$ cells are partially spared is central to any theory of the pathogenesis of MTS. The degree of excitation to which the cells are subjected is clearly important. $\mathrm{CA}_{2}$ neurons have minimal mossy fibre input from DG cells ${ }^{9}$ which may explain their sparing. However, the relative sparing of the DG cells themselves, which are directly excited by perforant pathway stimulation, needs to be explained. Many possible explanations have been offered. The distribution of glutamate receptors may be important: the highest concentration of NMDA-sensitive glutamate receptors in the CNS is found in $\mathrm{CA}_{1},{ }^{59.77}$ and there is a moderate concentration of NMDA receptors in $\mathrm{CA}_{3}$. However, kainate-sensitive glutamate receptors are found in high concentrations not only in $\mathrm{CA}_{3}$ but also in the resistant DG cells. Resistant cells admit no less calcium in response to glutamate stimulation than do vulnerable cells. ${ }^{14-116}$ Therefore, if calcium is pathogenetic, resistant cells must possess some protective mechanism.

Calcium binding proteins such as calbindin, parvalbumin and chromogranin A may exert protective influences. The distribution of calbindin and parvalbumin immunoreactivity is high in the pyramidal neurons of $\mathrm{CA}_{2}$ and in DG cells. ${ }^{17}$ Calbindin is decreased and parvalbumin is increased by kindling. ${ }^{118.119}$ However, in the perforant path stimulation model of hippocampal damage, calbindin neurons remain unaltered, whereas there is a marked loss of parvalbumin immunoreactive neurons. ${ }^{13}$ Another calcium binding protein, chromogranin $\mathrm{A}$, shares some domains with both calbindin and parvalbumin but unlike the latter proteins, it is located in Golgi apparatus and synaptic vesicles. ${ }^{120}$ Among hippocampal neurons, chromogranin A immunoreactivity has recently been shown to be predominantly expressed in DG cells and in the pyramidal cells of $\mathrm{CA}_{2}$ of humans. ${ }^{121} \mathrm{~A}$ protective role for the amino acid taurine is also under investigation, as it has been found in high concentrations in the $\mathrm{CA}_{2}$ cells of baboons. ${ }^{122}$ Greater ability of resistant cells to take up excitatory amino acids, thereby preventing their interaction with receptors, has been proposed but not proven. ${ }^{74.123-126}$

Seizure-induced entry of zinc into cortical neurons may contribute to cell death. ${ }^{127}$ Zinc released from excitatory synapses normally limits activation of the NMDA receptor and thus excitotoxicity. However, neuronal depolarization from AMPA receptor stimulation or high concentrations of $\mathrm{K}^{+}$may allow entry of zinc into neurons which may contribute to cell death.

\section{SUMMARY}

Current concepts indicate that seizures are both the cause and effect of mesial temporal sclerosis. Seizure activity arising anywhere for any reason can potentially reach the hippocampus via the entorhinal cortex. This leads to stimulation of DG cells and other hippocampal neurons via the perforant pathway. The DG cells send their axons, the mossy fibres, to $\mathrm{CA}_{3}$ neurons and release glutamate onto them, eventually causing cell death in $\mathrm{CA}_{3}$ (and ultimately $\mathrm{CA}_{1}$ ). $\mathrm{CA}_{2}$ cells are spared, possibly because of minimal mossy fibre input or possibly because of protective effects of calcium binding proteins. The latter would also protect the DG cells themselves. The seizures may cause release of NGF which leads to mossy fibre sprouting, resulting in recurrent DG cell excitation. Moreover, damage to $\mathrm{CA}_{3}$ and 
hilar cells may cause inhibitory basket cells to become dormant. Both of these mechanisms may result in abnormal excitability and subsequent perpetuation of seizures.

\section{ACKNOWLEDGEMENTS}

The authors would like to thank Dr. J.C.E. Kaufmann, Dr. C.L. Dewar and Dr. Stefan Brudzynski for their helpful suggestions, Mr. Taro Kaibara for contributing a figure, and Mrs. Maria Raffa for preparation of the manuscript.

\section{REFERENCES}

1. Earle KA, Baldwin M, Penfield W. Incisural sclerosis and temporal lobe seizures produced by hippocampal herniation at birth. Arch Neurol Psychiat 1953; 69: 27-42.

2. Margerison JH, Corsellis JAN. Epilepsy and the temporal lobes. A clinical, electroencephalographic and neuropathological study of the brain in epilepsy with particular reference to the remporal lobes. Brain 1966; 89: 499-530.

3. Falconer MA, Taylor DC. Surgical treatment of drug-resistant epilepsy due to mesial temporal sclerosis. Arch Neurol 1968; 19: 353-361.

4. Bruton CJ. The Neuropathology of Temporal Lobe Epilepsy. New York: Oxford University Press 1988.

5. Broca P. Anatomie comparée des circonvolutions cerebrales. Le grand lobe limbique et la scissure dans la serie des mammiferes. Rev Anthropol Paris 1878; 2: 285-498.

6. Papez JW. A proposed mechanism of emotion. Arch Neurol Psychiatry 1937; 38: 725-743.

7. MacLean PD. Some psychiatric implications of physiological studies on frontotemporal portion of limbic system. Electroencephalogr Clin Neurophysiol 1952; 4: 407-418.

8. Lopes da Silva FH, Witter MP, Boeijinga PH, Lohman AHM. Anatomic organization and physiology of the limbic cortex. Physiological Reviews 1990; 70: 453-511.

9. Lorente de Nó R. Studies on the structure of the cerebral cortex II. Continuation of the study of the Ammonic system. J Psychol Neurol 1934; 46: 113-177.

10. Amaral DG, Insausti R. Hippocampal formation. In: Paxinos G, ed. The Human Nervous System. San Diego: Academic Press 1990; 711-755.

11. Rose M. Der Allocortex bei tier und mensch. J Psychol Neurol 1926; 34: 1-99.

12. Lacaille J-C, Schwartzkroin PA. Stratum lacunosum-moleculare interneurons of hippocampal CA, region. I. Intracellular response characteristics, synaptic responses, and morphology. J Neurosci 1988; 8(4): 1400-1410.

13. Sloviter RS. Permanently altered hippocampal structure, excitability, and inhibition after experimental status epilepticus in the rat: the "dormant basket cell" hypothesis and its possible relevance to temporal lobe epilepsy. Hippocampus 1991; 1:41-66.

14. Sloviter RS, Damiano BP. On the relationship between kainic acid-induced epileptiform activity and hippocampal neuronal damage. Neuropharmacology 1981; 20: 1003-1011.

15. Sloviter RS. "Epileptic" brain damage in rats induced by sustained electrical stimulation of the perforant path. I. Acute electrophysiological and light microscopic studies. Brain Res Bull 1983; 10 675-697.

16. Scharfman HE, Schwartzkroin PA. Electrophysiology of morphologically identified mossy cells of the dentate hilus recorded in guinea pig hippocampal slices. J Neurosci 1988; 8(10): 38123821 .

17. Scharfman HE, Schwartzkroin PA. Responses of cells of the rat fascia dentata to prolonged stimulation of the perforant path: sensitivity of hilar cells and changes in granule cell excitability. Neuroscience 1990; 35: 491-504.

18. Witter MP. Connectivity of the rat hippocampus. In: Chan-Palay V, Köhler C, eds. The Hippocampus-New Vistas Neurology and Neurobiology. New York: Liss 1989: 53-69.

19. Witter MP, Amaral DG, Van Hoesen GW. The entorhinal-dentate projection in the macaque monkey: topographical organization along the longitudinal axis of the hippocampus. J Neurosci 1989: 9: 216-228.

20. Ramón y Cajal S. Estructura del asta de Ammon. Anat Soc Esp Histol Nat Madrid. 1893; 22: 53-114.

21. Blackstad TW. Commissural connections of the hippocampal region in the rat, with special reference to their mode of termination. J Comp Neurol 1956; 105: 417-537.

22. Rosene DL, Van Hoesen GW. The hippocampal formation of the primate brain. A review of some comparative aspects of cytoarchitecture and connections. In: Jones EG and Peters A, eds. Cerebral Cortex, Vol. 6. New York: Plenum Press 1987; 345-456.

23. Houser CR, Miyashiro JE, Swartz BE, Walsh GO, Rich JR, Delgado-Escueta AV. Altered patterns of dynorphin immunoreactivity suggest mossy fibre reorganization in human hippocampal epilepsy. J Neurosci 1990; 10: 267-282.

24. Bouchet C, Cazauvieilh JB. De l'epilepsie considerée dans ses rapports avec l'alienation mentale. Arch Gen Med 1825; 9: 510-542.

25. Meynert T. Studien uber das pathologisch-anatomiche material der Weine Irren-Anstalt. Vierteljahrssch Psychiat 1868; 3: 381-402.

26. Sommer W. Erkrankung des Ammonshorns als aetiologische moment der epilepsie. Arch Psychiat Nervenkr 1880; 10: 631-675.

27. Pfleger L. Beobachtungen über Schrumpfung und Sklerose des Ammonshorns bei Epilepsie. Allg Z Psychiat 1880; 36: 359-365.

28. Spielmeyer W. Die Pathogenese des epileptischen Krampfanfalles Histopathologischer Teil. Z Dtsch Gesellsch Neurol Psychiat 1927; 109: 501-520.

29. Scholz W. Die Krampfschädigungen des Gehirns. Monographien Gesamtgeb Neurol Psychiat 1951; 75, Berlin: Springer.

30. Gastaut H. Colloque sur les problemes d'anatomie normale et pathologique poses par les decharges epileptiques. Bruxelles: Editions Acta Medica Belgica 1956; 5-20.

31. Meyer A, Falconer MA, Beck E. Pathological findings in temporal lobe epilepsy. J Neurol Neurosurg Psychiatry 1954; 17: 276-285.

32. Norman RM. The neuropathology of status epilepticus. Med Sci Law 1964; 4: 46-51.

33. Ounsted C, Lindsay J, Norman R. Biological factors in temporal lobe epilepsy. Clin Dev Med. London: Heinemann Medical 1966; 22.

34. Veith G. Anatomische studie uber die Ammonshornsklerose im epileptikergehirn. Deutsche Zeitschrift fur Nervenheilkunde 1970; 197: 293-314.

35. Rocca WA, Sharbrough FW, Hauser WA, Annegers JF, Schoenberg BS. Risk factors for complex partial seizures: a population-based case-control study. Ann Neurol 1987; 21: 22-31.

36. Sagar HJ, Oxbury JM. Hippocampal neuron loss in temporal lobe epilepsy: correlation with early childhood convulsions. Ann Neurol 1987; 22: 334-340.

37. Mouritzen-Dam A. Epilepsy and neuron loss in the hippocampus. Epilepsia 1980; 21: 617-629.

38. Babb TL, Lieb JP, Brown WJ, Pretorius J, Crandall PH. Distribution of pyramidal cell density and hyperexcitability in the epileptic human hippocampal formation. Epilepsia 1984a; 25: $721-728$

39. Babb TL, Brown WJ, Pretorius J, Davenport C, Lieb JP, et al. Temporal lobe volumetric cell densities in temporal lobe epilepsy. Epilepsia 1984b; 25: 729-740.

40. Meldrum BS, Brierley JB. Neuronal loss and gliosis in the hippocampus following repetitive epileptic seizures induced in adolescent baboons by allylglycine. Brain Res 1972; 48: 361-365.

41. Meldrum BS, Brierley JB. Prolonged epileptic seizures in primates. Arch Neurol 1973; 28: 10-17.

42. Meldrum BS, Vigouroux RA, Brierley JB. Systemic factors and epileptic brain damage. Arch Neurol 1973; 29: 82-87.

43. Meldrum BS, Horton RW, Brierley JB. Epileptic brain damage in adolescent baboons following seizures induced by allylglycine. Brain 1974; 97: 407-418.

44. Meldrum BS, Nilsson B. Cerebral blood flow and metabolic rate early and late in prolonged epileptic seizures induced in rats by bicuculline. Brain 1976; 99: 523-542.

45. Meldrum BS. Metabolic effects of prolonged epileptic seizures and the causation of epileptic brain damage. In: Rose RC, ed. Metabolic Disorders of the Nervous System. London: Pitman 1981: $175-187$. 
46. Blennow G, Brierley JB, Meldrum BS, Siesjo BK. Epileptic brain damage: the role of systemic factors that modify cerebral energy metabolism. Brain 1978; 101: 687-700.

47. Babb TL, Brown WJ. Pathological findings in epilepsy. In: Engel $\mathrm{J}$, Jr, ed. Surgical Treatment of the Epilepsies. New York: Raven Press 1987; 22: 511-540.

48. Soderfeldt B, Kalimo H, Olsson Y, Siesjö BK. Histopathologic changes in the rat brain during bicuculline-induced status epilepticus. In: Delgado-Escueta AV, Wasterlain CG, Treiman DM, Porter RJ. eds. Advances in Neurology, Vol. 34: Status Epilepticus. New York: Raven Press 1983; 169-175.

49. Auer RN, Siesjo BK. Biological differences between ischaemia, hypoglycemia and epilepsy. Ann Neurol 1988; 24: 699-707.

50. Howse DC. Cerebral energy metabolism during experimental status epilepticus. In: Delgado-Escueta AV, Wasterlain CG, Treiman DM, Porter RJ, eds. Advances in Neurology, Vol. 34: Status Epilepticus. New York: Raven Press 1983; 209-216.

51. Blennow G, Nilsson B, Siesjo BK. Sustained epileptic seizures complicated by hypoxia, arterial hypotension or hyperthermia: effects on cerebral energy state. Acta Physiol Scand 1977; 100: 126-128.

52. Chapman A, Meldrum BS, Siesjo BK. Cerebral metabolic changes during prolonged epileptic seizures in rats. 3 Neurochem 1977; 28: 1025-1035.

53. Olney JW, Ho OL, Rhee V. Cytotoxic effects of acidic and sulphur-containing amino acids on the infant mouse CNS. Exp Brain Res 1972; 14:61-76.

54. Olney JW, Rhee V, Ho OL. Kainic acid: a powerful neurotoxic analogue of glutamate. Brain Res 1974; 77: 507-512.

55. Olney JW. Neurotoxicity of excitatory amino acids. In: McGeer EG, Olney JW, McGeer PL, eds. Kainic Acid as a Tool in Neurobiology. New York: Raven Press 1978; 95-121.

56. Buzsáki G. Feed-forward inhibition in the hippocampal formation. Prog Neurobiol 1984; 22: 131-153.

57. Lomo T. Patterns of activation in a monosynaptic cortical pathway: the perforant path input to the dentate area of the hippocampal formation. Exp Brain Res 1971; 12: 18-45.

58. Eccles JC. Excitatory and inhibitory mechanisms in brain. In: Jasper HH, Ward AA, Jr, Pope A, eds. Basic Mechanisms of the Epilepsies. Boston: Little, Brown and Company 1969; 229-252.

59. Cotman CW, Monaghan DT, Ottersen OP, Storm-Mathisen J. Anatomical organization of excitatory amino acid receptors and their pathways. Trends Neurosci 1987; 10:273-280.

60. Miller RJ. The revenge of the kainate receptor. Trends Neurosci 1991; 14: 477-479.

61. Lino M, Ozawa S, Tsuzuki K. Permeation of calcium through excitatory amino acid receptor channels in cultured rat hippocampal neurones. J Physiol 1990; 424: 151-165.

62. Andersen P. Properties of glutamate excitation of hippocampal pyramidal cells. In: Roberts PJ, Storm-Mathisen J, Johnston GAR, eds. Glutamate: Transmitter in the Central Nervous System. Chichester, UK: Wiley 1981; 25-33.

63. Fonnum F. Glutamate: a neurotransmitter in mammalian brain. J Neurochem 1984; 42: 1-11.

64. Hablitz JJ, Langmoen IA. Excitation of hippocampal pyramidal cells by glutamate in the guinea-pig and rat. J Physiol Lond 1982; 325: 317-331.

65. Madison DV, Lancaster B, Nicoll RA. Voltage clamp analysis of cholinergic action in the hippocampus. J Neurosci 1987; 7: 733-741.

66. Haas HL. Cholinergic disinhibition in hippocampal slices of the rat. Brain Res 1982; 233: 200-204.

67. Krnjevíc K, Ropert N, Casullo J. Septohippocampal disinhibition. Brain Res 1988; 438: 182-192.

68. Seress L, Ribak CE. GABAergic cells in the dentate gyrus appear to be local circuit and projection neurons. Exp Brain Res 1983; 50: 173-182.

69. Alger BE, Nicoll RA. Pharmacological evidence for two kinds of GABA receptor on rat hippocampal pyramidal cells studied in vitro. J Physiol Lond 1982; 328: 125-141.

70. Crunelli V, Assaf SY, Kelly JS. Intracellular recording from granule cells of the dentate gyrus in vitro. In: Seifert W, ed. Neurobiology of the Hippocampus. London: Academic 1983; 197-214.
71. Wong RKS, Watkins DJ. Cellular factors influencing GABA response in hippocampal pyramidal cells. J Neurophysiol 1982; 48: 938-951.

72. Numann RE, Wong RKS. Voltage-clamp study on GABA response desensitization in single pyramidal cells dissociated from the hippocampus of adult guinea pigs. Neurosci Lett 1984; 47: 289-294.

73. Crawford IL, Connor JD. Localization and release of glutamic acid in relation to the hippocampal mossy fibre pathway. Nature 1973; 244: 442-443.

74. Storm-Mathisen J, Leknes JAK, Bore AT, Line Vaaland J, Edminson $P$, et al. First visualization of glutamate and GABA in neurones by immunocytochemistry. Nature $1983 ; 301: 517-520$.

75. Rothman SM, Thurston JH, Hauhart RE. Delayed neurotoxicity of excitatory amino acids in vitro. Neuroscience 1987; 22: 471-480.

76. Sloviter RS, Dempster DW. "Epileptic" brain damage is replicated qualitatively in the rat hippocampus by central injection of glutamate or aspartate but not by GABA or acetylcholine. Brain Res Bull 1984; 15: 39-60.

77. Monaghan DT, Holets VR, Toy DW, Cotman CW. Anatomical distributions of four pharmacologically distinct ${ }^{3} \mathrm{H}-\mathrm{L}$-glutamate binding sites. Nature 1983; 306: 176-179.

78. Rogers BC, Barnes MI, Mitchell CL, Tilson HA. Functional deficits after sustained stimulation of the perforant path. Brain Res 1989; 493: 41-50.

79. Scheibel ME, Crandall PH, Scheibel AB. The hippocampal-dentate complex in temporal lobe epilepsy. Epilepsia 1974; 15: 55-80.

80. Olney JW, Fuller T, deGubareff T. Acute dendrotoxic changes in the hippocampus of kainate treated rats. Brain Res 1979; 76:91-100.

81. Nadler JV, Perry BW, Cotman CW. Intraventricular kainic acid preferentially destroys hippocampal pyramidal cells. Nature 1978; 271: 676-677.

82. Sloviter RS, Damiano BP. Sustained electrical stimulation of the perforant path duplicates kainate-induced electrophysiologic effects and hippocampal damage in rats. Neurosci Lett 1981;24: 279-284.

83. Nadler JV. Kainic acid as a tool for the study of temporal lobe epilepsy. Life Sci 1981; 29: 2031-2042.

84. Ben-Ari Y, Tremblay E, Ottersen OP, Meldrum BS. The role of epileptic activity in hippocampal and 'remote' cerebral lesions induced by kainic acid. Brain Res 1980; 191: 79-97.

85. Nadler JV, Cuthbertson GJ. Kainic acid neurotoxicity toward hippocampal formation: dependence on specific excitatory pathways. Brain Res 1980; 195: 47-56.

86. Cavazos J, Sutula T. Progressive neuronal loss induced by kindling: a possible mechanism in mossy fibre reorganization and hippocampal sclerosis [Abstract]. Epilepsia 1989; 30: 702.

87. Cavazos JE, Sutula TP. Progressive neuronal loss induced by kindling: a possible mechanism for mossy fibre synaptic reorganization and hippocampal sclerosis. Brain Res 1990; 527: 1-6.

88. Turski WA, Cavalheiro EA, Schwarz M, Czuczwar SJ, Kleinrok Z, et al. Limbic seizures produced by pilocarpine in rats: behavioural, electroencephalographic and neuropathological study. Behav Brain Res 1983; 9: 315-335.

89. Turski WA, Cavalheiro EA, Coimbra C, da Penha Berzaghi M, Ikonomidou-Turski C, et al. Only certain antiepileptic drugs prevent seizures induced by pilocarpine. Brain Res Rev 1987; 12: 281-305.

90. Nadler JV, Perry BW, Cotman CW. Selective reinnervation of hippocampal area $\mathrm{CA}_{1}$ and the fascia dentata after destruction of $\mathrm{CA}_{3}$ and $\mathrm{CA}_{4}$ afferents with kainic acid. Brain Res 1980; 182: 1-9.

91. Frotscher $M$, Zimmer J. Lesion-induced mossy fibres to the molecular layer of the rat fascia dentata: identification of postsynaptic granule cells by the golgi-EM technique. J Comp Neurol 1983; 215: 299-311.

92. Represa A, Robain O, Tremblay E, Ben-Ari Y. Hippocampal plasticity in childhood epilepsy. Neurosci Lett 1989; 99: 351-355.

93. Sutula T, Cascino G, Cavazos J, Parada I, Ramirez L. Mossy fibre synaptic reorganization in the epileptic human temporal lobe. Ann Neurol 1989; 26: 321-330.

94. de Lanerolle NC, Kim JH, Robbins RJ, Spencer D. Hippocampal interneuron loss and plasticity in human temporal lobe epilepsy. Brain Res 1989; 495: 387-395. 
95. Nadler JV, Perry BW, Gentry C, Cotman CW. Loss and reacquisition of hippocampal synapses after selective destruction of $\mathrm{CA}_{3}$ $\mathrm{CA}_{4}$ afferents with kainic acid. Brain Res 1980; 191: 387-403.

96. Represa A, Tremblay E, Ben-Ari Y. Kainate binding sites in the hippocampal mossy fibres: localization and plasticity. Neuroscience 1987; 20:739-748.

97. Sutula T, Xiao-Xian H, Cavazos J, Scott G. Synaptic reorganization in the hippocampus induced by abnormal functional activity. Science 1988; 239: 1147-1150.

98. Tauck DL, Nadler JV. Evidence of functional mossy fibre sprouting in hippocampal formation of kainic acid-treated rats. J Neurosci 1985; 5: 1016-1022.

99. Gall CM, Isackson PJ. Limbic seizures increase neuronal production of messenger RNA for nerve growth factor. Science 1989; 245: 758-761.

100. Springer JE, Loy R. Intrahippocampal injections of antiserum to nerve growth factor inhibit sympathohippocampal sprouting. Brain Res Bull 1985; 15: 629-634.

101. Thoenen H, Bandtlow C, Heumann R. The physiological function of nerve growth factor in the central nervous system: comparison with the periphery. Rev Physiol Biochem Pharmacol 1987; 109: 146-178.

102. Gahwiler BH, Enz A, Hefti F. Nerve growth factor promotes development of the rat septo-hippocampal cholinergic projection in vitro. Neurosci Lett 1987; 75: 6-10.

103. Goddard GV, Mclntyre DC, Leech CK. A permanent change in brain function resulting from daily electrical stimulation. Exp Neurol 1969; 25: 295-330.

104. Ernfors P, Bengzon J, Kokaia Z, Persson H, Lindvall O. Increased levels of messenger RNAs for neurotrophic factors in the brain during kindling epileptogenesis. Neuron 1991; 7: 165-176.

105. Gloor P. Epilepsy: relationships between electrophysiology and intracellular mechanisms involving second messengers and gene expression. Can J Neurol Sci 1989; 16: 8-21.

106. White JD. Gall CM, McKelvey JF. Enkephalin biosynthesis and enkephalin gene expression are increased in hippocampal mossy fibres following a unilateral lesion of the hilus. J Neurosci 1987; 7: 753-759.

107. Morris BJ, Feasey KJ, Bruggencate GT, Herz A, Höl!t V. Electrical stimulation in vivo increases the expression of prodynorphin m-RNA in rat hippocampal granule cells. Proc Natl Acad Sci USA 1988; 85: 3226-3230.

108. Evans M, Griffiths T, Meldrum BS. Early changes in the rat hippocampus following seizures induced by bicuculline or L-allylglycine: a light and electron microscopy study. Neuropathol Appl Neurobiol 1983; 9: 39-52.

109. Griffiths T, Evans M, Meldrum BS. Intracellular calcium accumulation in rat hippocampus during seizures induced by bicuculline or L-allylglycine. Neuroscience 1983; 10: 385-395.

110. Rothman S, Olney J. Excitotoxicity and the NMDA receptor. Trends Neurosci 1987; 10: 299-302.

111. Fifkova $E$, Van Harreveld A. Long-lasting morphological changes in dendritic spines of dentate granule cells following stimulation of the entorhinal area. J Neurocytol 1977; 6: 211-230.

112. Kandel ER, Schwartz JH. Directly gated transmission at central synapses. In: Kandel ER, Schwartz JH and Jessel TM, eds.
Principles of Neuroscience, Third edition. New York: Elsevier, 1991; 153-172.

113. Choi DW. Calcium mediated neurotoxicity: relationship to specific channel types and role in ischaemic damage. Trends Neurosci 1988; 11: 465-469.

114. Kudo Y, Ito K, Miyakawa H, Izumi Y, Ogura A, et al. Cytoplasmic calcium elevation in hippocampal granule cells induced by perforant path stimulation and L-glutamate application. Brain Res 1987; 407: 168-172.

115. Krnjevic K, Morris ME, Ropert N. Changes in free calcium ion concentration recorded inside hippocampal pyramidal cells in situ. Brain Res 1986; 374: 1-11.

116. Connor JA, Wadman WJ, Hockberger PE, Wong RKS. Sustained dendritic gradients of $\mathrm{Ca}^{2+}$ induced by excitatory amino acids in CA, hippocampal neurons. Science 1988; 240: 649-653.

117. Sloviter RS. Calcium binding protein (calbindin- $\mathrm{D}_{28} \mathrm{~K}$ ) and parvalbumin immunocytochemistry: localization in the rat hippocampus with specific reference to the selective vulnerability of hippocampal neurons to seizure activity. J Comp Neurol 1989; 280: 183-196.

118. Baimbridge KG, Mody l, Miller JJ. Reduction of rat hippocampal calcium-binding protein following commissural, amygdala, septal, perforant path and olfactory bulb kindling. Epilepsia 1985; 26: $460-465$

119. Kamphuis W, Huisman E, Wadman WJ, Heizmann CW, Lopes da Silva FH. Kindling-induced changes in parvalbumin immunoreactivity in rat hippocampus and its relation to long-term decrease in GABA immunoreactivity. Brain Res 1989; 479: 23-24.

120. lacangelo A, Affolter H-U, Eiden LE, Herbert E, Grimes M. Bovine chromogranin-A: sequence and distribution of its messenger RNA in endocrine tissues. Nature 1986; 323: 82-86.

121. Munoz DG. The distribution of chromogranin A-like immunoreactivity in the human hippocampus coincides with the pattern of resistance to epilepsy-induced neuronal damage. Ann Neurol 1990; 27: 266-275.

122. Ottersen OP, Madsen S, Meldrum BS, Storm-Mathisen J. Taurine in the hippocampal formation of the Sengalese baboon. Papio papio: an immunocytochemical study with an antiserum against conjugated taurine. Exp Brain Res 1985; 59: 457-462.

123. Storm-Mathisen J, Iversen LL. Uptake of $\left[{ }^{3} \mathrm{H}\right]$ glutamic acid in excitatory nerve endings: light and electron microscopic observations in the hippocampal formation of the rat. Neuroscience 1979; 4: 1237-1253.

124. Storm-Mathisen J, Wold JE. In vivo high affinity uptake and axonal transport of $\mathrm{D}-\left[2-3-{ }^{3} \mathrm{H}\right]$ aspartate in excitatory neurons. Brain Res 1981; 230: 427-433.

125. Taxt T, Storm-Mathisen J. Uptake of D-aspartate and L-glutamate in excitatory axon terminals in hippocampus: autoradiographic and biochemical comparison with GABA and other amino acids in normal rats and in rats with lesions. Neuroscience 1984; 11: 79-100.

126. Heggli DE, Aamodt A, Malthe-Sorenssen. Kainic acid neurotoxicity: effect of systemic injection on neurotransmitter markers in different brain regions. Brain Res 1981; 230: 261-262.

127. McNamara JO. The neurobiological basis of epilepsy. Trends Neurosci 1992; $15: 357-359$. 